\title{
Minimizing Theft on Construction Sites in Ghana: The Perspective of Contractors in the Upper West Region of Ghana
}

\author{
Ephraim Elikem Ablordeppey $^{1 *} \quad$ Fortunatus Moo $^{1} \quad$ Wisdom Akortsu ${ }^{1} \quad$ Ameen Mustapha $^{2}$ \\ 1.School of Applied Science and Technology, Department of Building Technology and Estate Management, Wa \\ Polytechnic, P.O box 553, Ghana. \\ 2.Ghana Highway Authority - Wa
}

\begin{abstract}
Theft has been recognized as a major problem in the construction industry. Theft have an impact on the potential profitability of a construction project and also on the overall success of the construction industry. This research is set out to explore the most efficient and appropriate security measures to employ at construction sites in Ghana that would minimize or eliminate the incidence of theft on construction sites. This study was conducted in the upper west region of Ghana with a relatively homogenous population of contractors. The study was conducted using a quantitative research approach in which questionnaires were administered to contractors. The results from the analysis of the data ranked various security measures based on their Mean of frequency. Lighting of sites, fencing of sites and locking of gates were ranked above other security measures as being more efficient in preventing theft both when construction sites are located in densely and sparsely populated areas. The results indicated that employment of watchman is the most efficient and most used security measure on construction sites with security cameras, alarm systems and warning signs constituting the least used security measures. Effective implementation of the most critical security measures whiles giving some consideration to other security measures would most likely protect sites from theft whiles ensuring that value for money invested in securing sites is also achieved.
\end{abstract}

Keywords:Building materials, construction sites, plants, Security, theft, watchman.

DOI: $10.7176 /$ CER/12-5-03

Publication date:May $31^{\text {st }} 2020$

\section{Background}

In Ghana, the construction industry has been 'plagued' with numerous negative factors notable among which is theft on construction sites; of building materials, plants and equipment, small tools, appliances, among other items. Thieves and vandals can directly impact the success of a project and diminish the potential profitability of the project under construction. Construction site theft is a considerable problem in the construction industry and will continue to be a threat (Farinloye et al., 2009). Theft is costlier to large firm sized than smaller firms and this occurs despite the fact that larger firms use a greater number of measures to combat theft on their construction sites (Berg, 2005). The Annual losses to the building industry as a result of criminal activities run into millions of dollars and, according to most industry stakeholders, losses are escalating each year (BSCP, 2002). In the United Kingdom for instance, it is estimated that cost of theft of construction plant is around $£ 500$ million (CITS, 2011). Previous studies in the US has also shown that many construction firms do not report the theft of items that are valued less than the company's insurance deductible amount. This has made it very difficult to know the magnitude of theft in the construction industry. Since the year 2000, more than $\$ 69.7$ million worth of stolen assets has been recovered as a direct result of LoJack (LoJack, 2006). According to LoJack, 2006 the equipment recovery data illustrated the most popular types of equipment targeted by thieves. This equipment includes: Backhoe Loaders, skid steers, Generators/air compressors/welders, Forklifts and Scissor Lifts, Light towers and Light Utility/Work Trucks and Trailers. Waste in construction resulting from theft is under the category of avoidable - waste, as it has a significant potential of being minimized or even at best, being completely eliminated. According to BSCP 2002, a stolen piece of equipment or material can close the whole job down temporarily and Insurance costs are bound to rise. As Lang (2008) suggested, "a drive to squeeze out intruders, thieves and vandals and enforce measures to improve jobsite security has been on the increase". The implication being that several attempts had been made in the past and are still being made to curb the problem of theft on construction sites. However, focus of attention has been on the effects of theft (mainly plant theft) to the construction industry rather than the causes. Determining the significances of the causes of theft will enhance the development of appropriate strategy for mitigating theft. And also, little has been done to investigate the effectiveness/significance of component of security on building sites. The processes involved in plant theft include identification, access, activation, removal, processing, transportation and resale (Edwards et al., 2007). The main objective of this study is to examine measures of minimizing theft on construction sites in the Wa Municipality of the Upper West Region of Ghana.

\section{Literature Review}

Despite the fact that the construction industry in Ghana contributes a considerable portion to the Gross Domestic 
Product (GDP) of the country, it has 'suffered' a lot as a result of problems arising from theft of materials, equipment and plants used for construction. Theft of construction equipment and materials is widely considered a common and widespread problem. However, it is difficult to estimate the scale of the problem due to the lack of official statistics identifying building site crime, and the absence of specific reporting code for police investigation. Moreover, the number of incidents of theft may be underestimated, as many incidents are unlikely to be reported to the police (Smith \& Walmsley, 1999). Jobsite security is an often-ignored facet of commercial construction projects in Ghana. Theft on construction sites is not a peculiarity of the Ghanaian construction industry alone but runs throughout the whole world. According to the Japan Construction Equipment Manufacturers Association (JCEMA), more than 1,000 construction machines were stolen in 2001 alone in Japan (Rental Equipment Registrar Magazine, 2002). According to insurer Zurich Canada, in Canada, the losses totaled at least 32 million dollars, with annual insurance claims representing more than 46 million dollars (The Mechanical Contractors Association of Toronto Fall, 1999). A 1990 survey conducted by the Associated General Contractors (AGC) indicated that the average contractor loses more than 13,000 dollars a year from theft (Banks, 1990).

\subsection{Theft}

Theft is defined as the unauthorized removal of any material or equipment from a job site (Yulia, 2008). A person is guilty of theft if he dishonestly appropriates property belonging to another with the intention of permanently depriving the other of it. According to Longman Active Study Dictionary $6^{\text {th }}$ edition. (2015), theft is the crime of stealing something from a person or place.

\subsection{An Overview of Theft in the Construction Industry}

Construction sites are eye catching places. People passing by may stop to see what is being built or may even walk through the site. The simple curiosity that draws many people to construction sites also increases the probability that some people will then trespass or take unprotected property from the site.

According to (Farinloye, 2013), every year building contractors in the construction industry loose considerable sums of money as a result of theft. These losses will continue to occur unless appropriate precautions are taken which can make the difference between a company's success and its failure. It is essential that construction companies/contractors report all losses due to theft to the local police department or Security Company. Attention should be paid particularly on the security of construction materials on site. Builders should minimize the time that materials are left on site before installing them and where and when possible enforce justin-time deliveries. Also, they should focus on providing extra security especially when and where workers jobs are terminated to avoid vandalism.

Though the construction industry uses extensive labour resources, it has increasingly become reliant on mechanization (Harris, 1994). The consequence of such extensive mechanization is the "temptation" for plant theft (Carmichael et al., 2007). In the terminology of routine activity theory (Felson, 1998), the construction sites ensured the convergence of many suitable targets for theft, an absence of capable guardians, and a ready supply of likely offenders.

\subsection{Perpetrators of Theft on Construction Sites}

The perpetrators of construction site theft include amateur opportunists, professional thieves and construction operatives (Boba and Santos, 2006). A number of studies of household burglary have also found that burglars tend to commit their offenses close to where they live and that their victims have some knowledge of their identities (Mawby, 2001).

Professional criminals are often thought to be involved in illegal activities within the construction industry, especially theft of heavy plant and equipment. Professional thieves are organized criminals who steal higher value plant and equipment (Edwards et al., 2007). While you may not be able to keep professional thieves from stealing your property, you can make it extremely difficult for them.

Insiders or construction operatives also pose a significant threat of theft at the site.

Insiders may be more likely to take tools and small equipment or items. Estimates of the amount of revenue lost through the varying forms of employee theft are difficult to identify. Much of employee theft goes undetected or is not publicized by the employer. A director of security testing for London House states that very few employees ever get caught stealing, and he believes as much as 80 percent of employee theft goes undetected (Green, 1997; Zemke, 1986), while Taylor (1986) believes only 5 percent of the employees stealing from a firm are apprehended. Furthermore, many of the estimates of employee theft are based on surveys that are completed by employees and employers which may lead to underreporting of employee theft rates (Kamp and Brooks, 1991). Although equipment theft can be opportunistic, given the size of the equipment and the specialist assistance required in locating, moving and shipping the machines overseas, as well as selling them on, it is more common to find serious and organized criminal gangs involved (Purbrick, 2003).

There are other forms of theft from building sites. These include theft by workers of tools and materials, after- 
hours pilfering of timber and other materials by opportunist thieves and thefts by habitual offenders and others of fixtures and appliances (Clarke \& Goldstein, 2003). Previous studies found that theft of smaller and transportable equipment was much more prevalent than theft of heavy equipment (Smith \& Walmsley, 1999; Jeffrey, 2001; Clarke \& Goldstein, 2003).

\subsection{Magnitude and Cost of Construction Site Theft}

Although there is insufficient statistics to support the magnitude of construction theft in Ghana, statistics from other countries around the world will inform us of a fair idea of how 'huge' the magnitude of construction theft is. In United Kingdom a survey was carried out by Smith and Walmsley (1999) shows that construction theft risk is at 26 per 1000 items of equipment in use. They further suggested that the annual cost of theft to construction could be in excess of $£ 600$ million (GH£3,640,940,280.00). The National Plant and Equipment Register (TER) (2009) records 3,678 plant thefts at a value of $£ 36$ million $(\mathrm{GH} \notin 218,369,438.75)$ with a recovery rate below $5 \%$. Allianz (2011) stated that insurers' records indicate theft of construction plant to be over 24,000 pieces of equipment with a depreciated cost of equipment stolen per annum of $£ 70$ million ( $\mathrm{GH} \notin 424,607,242.01)$. Plant theft victims pay $£ 7500(\mathrm{GH} \notin 45,493,633,072.50)$ per theft from loss of productivity, hire of alternative plant, etc., and if the stolen plant is recovered, the victims pay "open-ended" recovery and cross hire costs (KOSRAN, 2011). More also, according to the National Association of Home Builders (NAHB), the theft of backhoes and other heavy equipment, tools, building materials, and appliances costs the home building industry 4 billion a year and inflates the cost of the average new home by 1.5 percent, or more than 4,000 (O'Malley, 2005). While these costs of plant and equipment theft are considerable, the true value of stolen plant is likely to be more than double because of underreporting, this is mainly due to the fact that less than $40 \%$ of plant is insured (Gregory, 2007). The calculations of the financial losses of plant theft vary significantly for reasons such as inaccuracy in valuing stolen plant, differences in valuation methods (depreciated or new-for-old) and whether indirect costs are included or not (Carmichael et al., 2007). The direct costs of plant theft are replacement value (new-for-old) and residual value (depreciated) while the indirect costs include emergency cost, hire replacement cost, productivity loss, increased labour cost, loss of goodwill, administration cost, increased insurance premiums and social costs such as dealing with trauma and stress (Edwards et al., 2007).

\section{Research Methodology}

In this research, a quantitative approach was used because it is an objective measurement of the problem. It investigates facts and tries to establish relationships between these facts. A quantitative approach was used to determine the effectiveness and the frequent use of the current security practices or measures on construction sites; the impact of construction site location on the incidence of theft; perpetrators of theft on the construction site and; the vulnerability of plants, materials and equipment on the construction site to theft.

This study was geared towards examining carefully selected security factors (measures) obtained from a careful and detailed review of literature and previous research works relating to minimizing theft at construction sites. The aim is to show the degree of influence these security measures had in reducing or at best, eliminating the incidence of theft at construction sites.

Seven (7) main security measures (factors) were considered in the study. The dependent variable of this study is the reducing construction site theft. The independent variables are the security measures. 


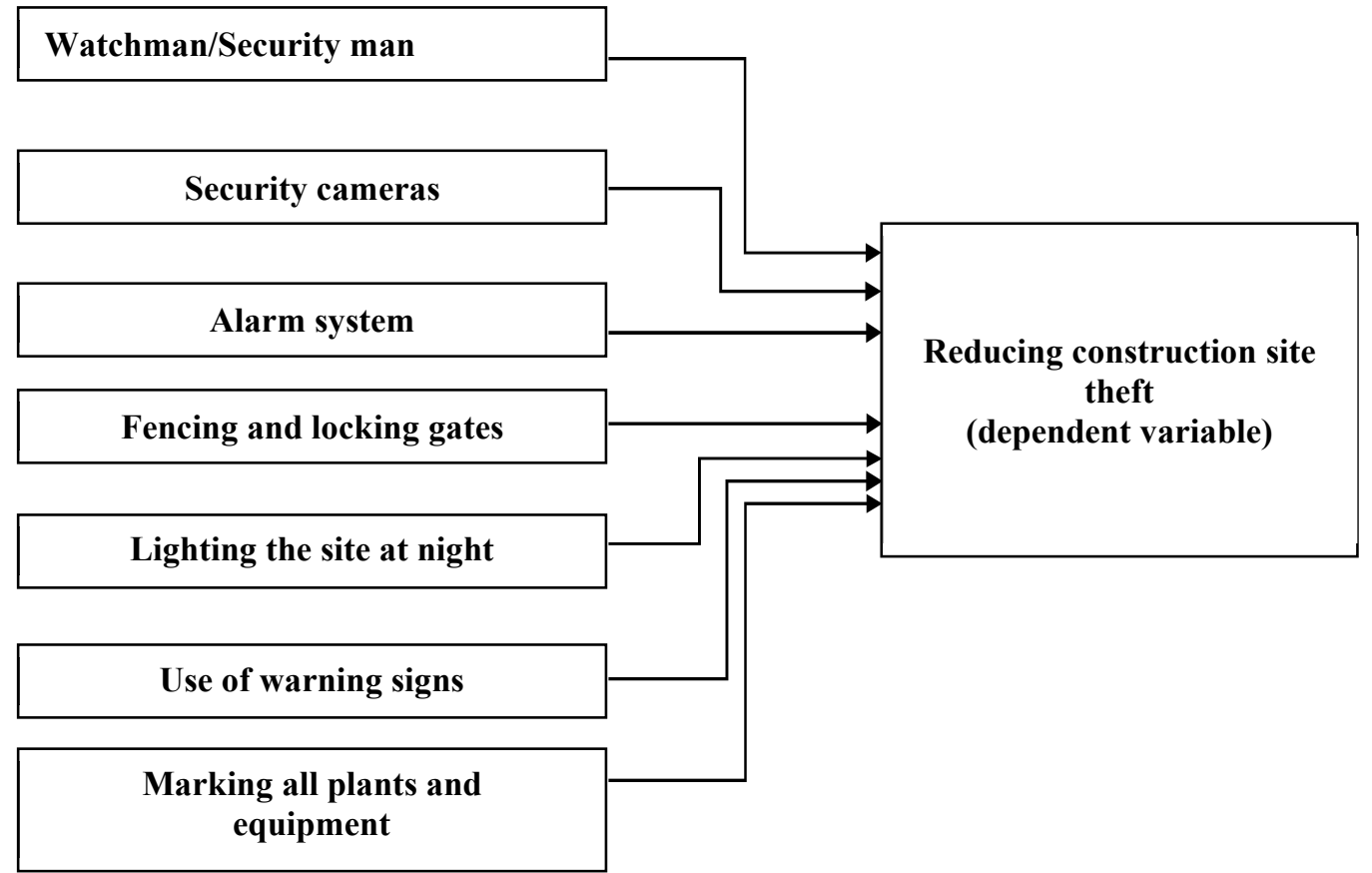

Figure 1. Diagram showing seven independent security measures and one dependent variable (Source: https://h6.googleusercontent.com)

The research employed non-probability sampling techniques. To help achieve a representation of building and civil engineering contractors in the Upper West Region Snowball sampling technique was used to select respondents. For the purpose of the fieldwork, a total of Thirty Three (33) respondents comprising contractors and their workers, were chosen from various companies within the Upper West Region of Ghana.

Data was analyzed with Statistical Package for Social Sciences (SPSS) and Microsoft Excel. Tables, charts and percentages of the data gathered among others were used in the case of the quantitative technique, while descriptions were also used in the case of the qualitative analysis. The questionnaires item that has the highest responses was considered the general view of the respondents. Results of the findings were based on the statistical outcome of the responses given through the interview and administration of the questionnaires by the researchers.

\section{Discussions and Interpretation of Results}

\subsection{Forms of Construction Work Undertaken by Contractors}

The forms of construction works were categorized under three main headings, namely, General building works, Civil engineering works and both Building and Civil works. Seventeen (52\%) of the thirty-three contractors who responded mainly execute general building works, nine $(27 \%)$ of the contractors undertake civil engineering works and seven (21\%) carry out both building and civil engineering works.

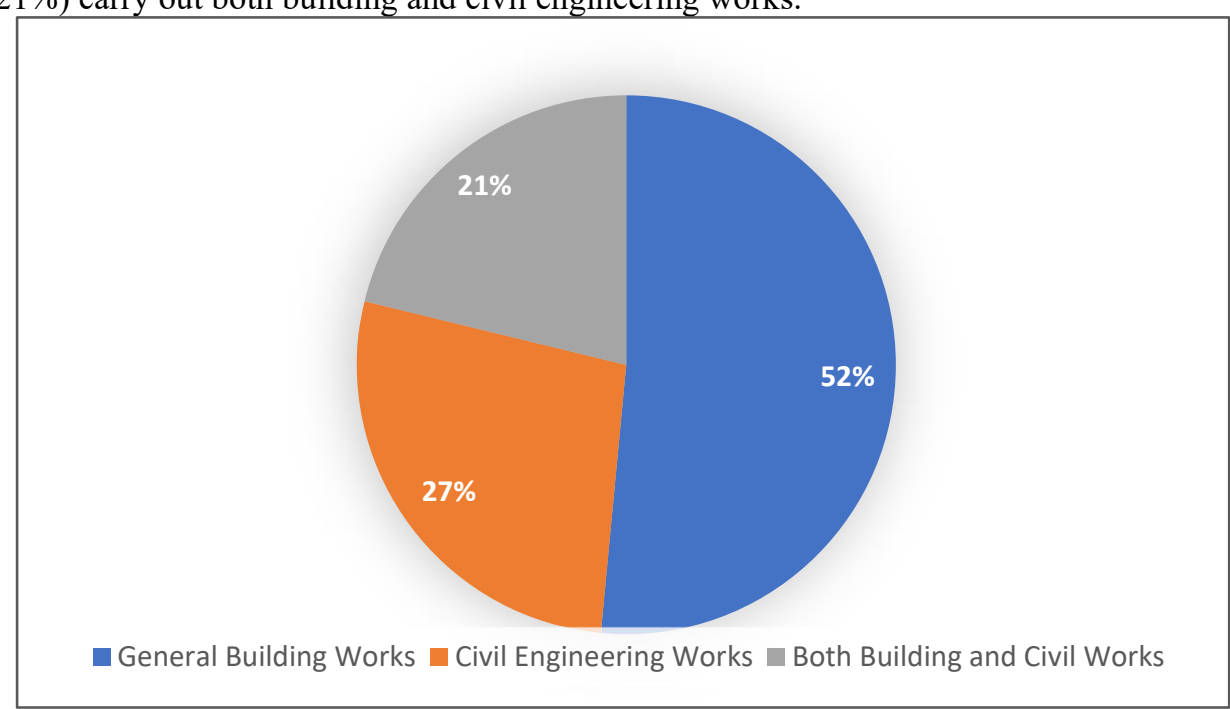

Figure 2 Form(s) of construction works contractors carry out 


\subsection{Classification of Contractors}

All building and civil engineering contractors were classified according to the classification by the Ministry of Water Resources Works and Housing (MWRWH) of the republic of Ghana. Whereas building contractors were classified as $D_{1}, D_{2}, D_{3}$ and $D_{4}$, civil engineering contractors were also classified as $K_{1}, K_{2}, K_{3}$ and $K_{4}$ (in a descending order of importance). However, the categories for both building and civil contractors were combined as one for each class (such as $\mathrm{D}_{1} / \mathrm{K}_{1}, \mathrm{D}_{2} / \mathrm{K}_{2}, \mathrm{D}_{3} / \mathrm{K}_{3}$ and $\mathrm{D}_{4} / \mathrm{K}_{4}$ ). Of the thirty-three respondence Eighteen representing $55 \%$ of contractors were having $\mathrm{D}_{2} / \mathrm{K}_{2}$ construction certificate, Ten i.e $30 \%$ contractors were having $\mathrm{D}_{3} / \mathrm{K}_{3}$ construction certificate, Three $(9 \%)$ were under $\mathrm{D}_{4} / \mathrm{K}_{4}$ category and Two $(6 \%)$ contractors were under the category of $\mathrm{D}_{1} / \mathrm{K}_{1}$.

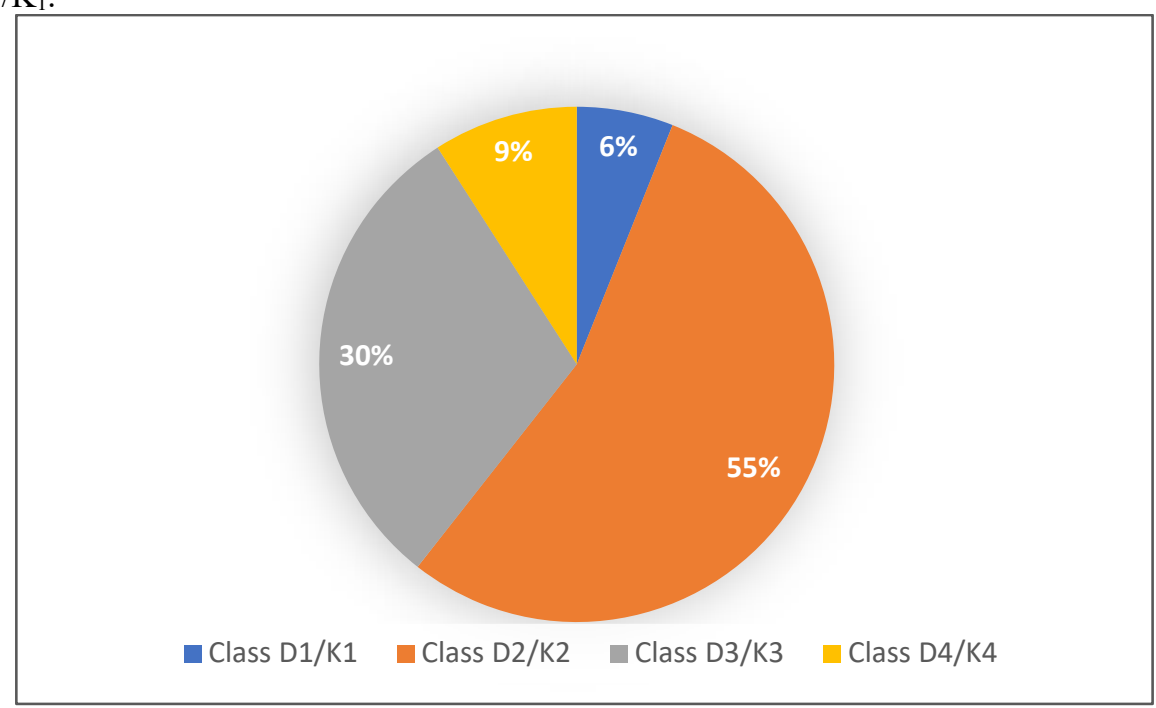

Figure 3 Classification of contractors in the Upper West Region

\subsection{Analysis of Research Questions}

The mean rating for each item was computed for each of the respondents. The resultant mean rating for the items was also computed thereafter, the computed mean ratings were compared with the theoretical mean rating of 3.0 to determine respondents' views on the questionnaire. Any computed mean relating to the research question exceeding 3.00 indicate respondent positive expression of views whiles mean values below 3.00 indicated respondent negative expressions of views.

\subsubsection{Severity of Security Measures Based on Location of Construction Sites}

The impact of the location of construction sites on the incidence of theft was examined by asking respondents to give their views on the intensity of the various security measures both when they are employed on sites that are located in densely populated and sparsely populated areas. The security measures were tested under two scenarios - when construction sites are located in densely populated areas and when they are located in sparsely populated areas and their respective rankings are depicted in table 1

The contrctors express negative views towards empolying security cameras and alarm systems as securrity measure to curb/preventing construction site theft at both densely and sparsely populated areas. This implies that they both don't necessarily have much impact in preventing theft at construction site in both densely and sparsely populated areas as compared to other security measures in the study area. Table $1 . \quad$ Severity of security measures based on location of construction sites 
A) Intensity of security measures in preventing theft on construction sites that are situated in DENSELY populated areas

\begin{tabular}{|c|l|c|c|c|c|}
\hline \multicolumn{1}{|c|}{ Item } & N & Mean & $\begin{array}{c}\text { Std. } \\
\text { Deviation }\end{array}$ & Rank \\
\hline 1 & \multicolumn{1}{|c|}{ Watchman/Security man } & 33 & 3.636 & 1.558 & $3 \mathrm{rd}$ \\
2 & Security cameras & 33 & 2.727 & 0.911 & 7 th \\
3 & Alarm systems & 33 & 2.758 & 0.830 & 6 th \\
4 & Fencing and locking gates & 33 & $\mathbf{3 . 7 5 8}$ & 1.226 & $1 \mathrm{st}$ \\
5 & Lighting the site at night & 33 & $\mathbf{3 . 7 5 8}$ & 1.347 & $2 \mathrm{nd}$ \\
6 & Use of warning signs & 33 & 3.091 & 1.071 & 5 th \\
7 & Marking all plants and equipment & 33 & 3.576 & 1.061 & $4 \mathrm{th}$ \\
\hline
\end{tabular}

B) Intensity of security measures in preventing theft on construction sites that are situated in SPARSELY populated areas

\begin{tabular}{|c|l|c|c|c|c|}
\hline \multicolumn{1}{|c|}{ Item } & N & Mean & $\begin{array}{c}\text { Std. } \\
\text { Deviation }\end{array}$ & Rank \\
\hline 1 & Watchman/Security man & 33 & $\mathbf{3 . 5 1 5}$ & 1.584 & $3 \mathrm{rd}$ \\
2 & Security cameras & 33 & 2.788 & .960 & 6 th \\
3 & Alarm systems & 33 & 2.727 & 1.008 & 7 th \\
4 & Fencing and locking gates & 33 & $\mathbf{3 . 5 1 5}$ & 1.302 & $2 \mathrm{nd}$ \\
5 & Lighting the site at night & 33 & $\mathbf{3 . 6 3 6}$ & 1.113 & $1 \mathrm{st}$ \\
6 & Use of warning signs & 33 & 3.060 & 1.088 & 5 th \\
7 & Marking all plants and equipment & 33 & 3.182 & 1.074 & 4 th \\
\hline
\end{tabular}

\subsubsection{Vulnerability of Plants, Materials and Tools to Theft}

Data was also collected on how vulnerable the various materials, plants and tools are prone to theft on construction sites. As identifying such materials, plants and tools usually prone to theft will help inform us of the ones that require more emphasis to be placed on and also the most appropriate and efficient security measures to adopt. The levels on the ordinal scale included 'very often', 'often', 'neutral', 'less often' and 'not often'. The levels are an indication of how frequently theft of the various materials, plants and tools occur on sites with 'very often' denoting the highest frequency, whilst, 'not often' denotes least frequency of occurrence and ranking was used to indicate the highest material prone to theft at the construction site. Thirty-three responses were received and of these, 'general building materials' was ranked 1st as very often and 'small tools and equipment' was ranked 2nd as 'very often', respondents respectively rated 'heavy plants and machinery' as 'less often' and 'not often'.

Table 2. Degree at which plants, materials, and equipment are stolen on sites.

\begin{tabular}{|l|l|c|c|c|c|}
\hline S/N & Item & $\mathbf{N}$ & Mean & $\begin{array}{c}\text { Std. } \\
\text { Deviation }\end{array}$ & Rank \\
\hline 1 & $\begin{array}{l}\text { General building material (e.g. cement, plywood, lumber, } \\
\text { tiles, blocks etc.) }\end{array}$ & 33 & 3.515 & 1.584 & $1 \mathrm{st}$ \\
\hline 2 & $\begin{array}{l}\text { Small tools and equipment (e.g. headpans, wheelbarrows, } \\
\text { scaffolds etc.) }\end{array}$ & 33 & 3.030 & 0.984 & $2 \mathrm{nd}$ \\
\hline 3 & $\begin{array}{l}\text { Heavy plants and machinery (e.g. forklifts, dumpers, tipper } \\
\text { trucks etc.) }\end{array}$ & 33 & 2.121 & 0.960 & $3 \mathrm{rd}$ \\
\hline
\end{tabular}

4.3.3 Intensity of Security Measures in Protecting Plants, Building Materials and Tools from Theft

The survey had a question on the intensity of security measures in protecting the various plants, materials and tools from being stolen on construction sites. Respondents were given a list of security measures available for use by construction firms and asked to rank them in terms of how intensive each of them is in protecting the building materials from being stolen. Upon the responses of the contractors, the various security measures were allocated scores and they were then ranked from first to seventh $\left(1^{\text {th }}-7^{\text {th }}\right)$ based on their intensity in protecting the plants, materials and tools from theft. The results are summarized in table 3.

Lighting the site at night, fencing and locking gates and watchman/security men: were highly rated security measures in protecting building materials, small tools and plants from theft with approximately 3.5 and above. This implies that those three security measures should be given first priority in terms of reducing construction site theft. 
Table 3. Intensity of security measures in protecting building materials, small tools and plants from theft

\begin{tabular}{|c|c|c|c|c|c|}
\hline \multicolumn{6}{|c|}{ A) General Building Materials (E.G. Cement, Plywood, Lumber, Tiles etc.) } \\
\hline $\mathbf{S} / \mathbf{N}$ & Item & $\mathbf{N}$ & Mean & $\begin{array}{c}\text { Std. } \\
\text { Deviation }\end{array}$ & Rank \\
\hline 1 & Watchman/Security man & 33 & 3.636 & 1.558 & 3 rd \\
\hline 2 & Security cameras & 33 & 2.909 & 0.911 & 6 th \\
\hline 3 & Alarm systems & 33 & 2.606 & 0.830 & 7 th \\
\hline 4 & Fencing and locking gates & 33 & 3.667 & 1.226 & 2nd \\
\hline 5 & Lighting the site at night & 33 & 3.758 & 1.347 & $1 \mathrm{st}$ \\
\hline 6 & Use of warning signs & 33 & 3.061 & 1.071 & 5 th \\
\hline 7 & Marking all plants and equipment & 33 & 3.212 & 1.061 & 4th \\
\hline \multicolumn{6}{|c|}{ B) Small Tools and Equipment (e.g. head pans, shovels, wheelbarrows etc.) } \\
\hline $\mathbf{S} / \mathbf{N}$ & Item & $\mathbf{N}$ & Mean & $\begin{array}{c}\text { Std. } \\
\text { Deviation }\end{array}$ & Rank \\
\hline 1 & Watchman/Security man & 33 & 3.606 & 1.619 & 2nd \\
\hline 2 & Security cameras & 33 & 3.152 & 1.064 & 4 th \\
\hline 3 & Alarm systems & 33 & 2.394 & 0.899 & 7 th \\
\hline 4 & Fencing and locking gates & 33 & 3.485 & 1.326 & $3 \mathrm{rd}$ \\
\hline 5 & Lighting the site at night & 33 & 3.636 & 1.270 & $1 \mathrm{st}$ \\
\hline 6 & Use of warning signs & 33 & 3.061 & 1.197 & 5 th \\
\hline 7 & Marking all plants and equipment & 33 & 2.636 & 0.929 & 6 th \\
\hline \multicolumn{6}{|c|}{ C) Heavy Plants and Machinery (e.g. Concrete mixers, Tipper trucks, Dumpers) } \\
\hline $\mathbf{S} / \mathbf{N}$ & Item & $\mathbf{N}$ & Mean & $\begin{array}{c}\text { Std. } \\
\text { Deviation }\end{array}$ & Rank \\
\hline 1 & Watchman/Security man & 33 & 3.364 & 1.517 & $3 \mathrm{rd}$ \\
\hline 2 & Security cameras & 33 & 2.788 & 1.111 & 7 th \\
\hline 3 & Alarm systems & 33 & 2.879 & 1.166 & 6 th \\
\hline 4 & Fencing and locking gates & 33 & 3.515 & 1.482 & 2nd \\
\hline 5 & Lighting the site at night & 33 & 3.636 & 1.388 & $1 \mathrm{st}$ \\
\hline 6 & Use of warning signs & 33 & 2.970 & 1.185 & 4th \\
\hline 7 & Marking all plants and equipment & 33 & 2.970 & 1.287 & 5 th \\
\hline
\end{tabular}

\subsubsection{Perpetrators of Theft at Construction Sites}

The survey asked respondents to speculate on the group(s) of people that commit theft on construction sites. Theft perpetrators were grouped under three categories, namely,

Insiders, outsiders and collaboration between both insiders and outsiders. Insiders here consist mainly of employees working on and off the site and they include both skilled and unskilled labour, management and technical personnel usually engaged by the contractors to render some services. Outsiders mainly consist of visitors, passers-by, trespassers and all other unauthorized people who are not employed by the contractor to carry out the works.

Five respondents (15\%) believed that thefts on construction sites are mainly committed by insiders, Six (18\%) consider the act of theft as mainly coming from outsiders and Twenty-Two (67\%) respondents believed that incidences of thefts are caused by collaboration between insiders and outsiders. The table below portray a picture of their responses.

Table 4. Perpetrators of theft at construction site

\begin{tabular}{lll} 
Items & Frequency & Percent \\
\hline Insiders & 5 & $15 \%$ \\
Outsiders & 6 & $18 \%$ \\
Collaborators & 22 & $67 \%$
\end{tabular}

The survey also revealed that comparing the degree to which thefts occur at site with respect to insiders and outsiders. 'Outsiders' was ranked first (1st) as being the main theft perpetrators at the construction site. Respondents also rated 'insiders' as 'often', as being the most perpetrators of theft at the construction site. 
Table 5. Degree of thefts from insiders and outsiders

\begin{tabular}{|l|c|c|c|c|}
\hline Item & N & Mean & Std. Deviation & Rank \\
\hline Insiders & 33 & 3.515 & 1.544 & $2 \mathrm{nd}$ \\
Outsiders & 33 & 3.939 & 1.273 & $1 \mathrm{st}$ \\
\hline
\end{tabular}

4.3.5 Degree of Theft from Different Categories of Insiders

Insiders were further divided into three categories, namely, management and technical staff, skill labour (artisans) and unskilled labour. Respondents' views were further sought to determine the degree to which theft occur from these different classes of insiders.

Table 6. Degree of theft from mgt. and technical staff and skilled and unskilled labourers.

\begin{tabular}{|l|c|c|c|c|}
\hline Item & N & Mean & Std. Deviation & Rank \\
\hline Management and Technical Staff & 33 & 2.667 & 1.164 & $3^{\text {rd }}$ \\
\hline Skilled labourers & 33 & 3.394 & 1.088 & $2^{\text {nd }}$ \\
\hline Unskilled labourers & 33 & 3.697 & 1.185 & $1^{\text {st }}$ \\
\hline
\end{tabular}

4.3.6 Appropriate Security Measures for Tackling Thefts from Outsiders and the Various Categories of Insiders.

Open ended questions were formulated to seek the views of contractors on the most appropriate and efficient security measures that will counteract thefts from both outsiders and the different categories of insiders, namely, management and technical staff, skilled labourers and unskilled labourers. Respondents proposed similar security measures as to those earlier on mentioned. They included employing the services of watchmen, use of security cameras, using alarm systems, lighting site at night, fencing the sites and locking all gates, use of warning signs and the marking of plants. Some additional security measures or factors for curbing thefts from the various categories of people, however, were mentioned by some respondents.

These security measures consisted of the following:

Outsiders

- Decreasing their contact with insiders

- Restriction of their access to sites

Management and technical staff

- $\quad$ Ensuring adequate supervision

- Monitoring their movement in and out of site

- Making them take responsibility for all theft incidences that occur on site

- Use of sanctions

Skilled labourers

- Ensuring adequate supervision

- Monitoring their activities on site

- Ensuring all materials, equipment and tools are secured and locked inside storage rooms immediately after use.

- $\quad$ keeping keys to storage rooms in the care of only supervisors

- Rotation of workers

- Screening all workers before they exit site

Unskilled labourers

- $\quad$ Ensuring adequate supervision

- Ensuring all materials, equipment and tools are secured and locked inside storage rooms immediately after use.

- Screening all workers before they exit site

- Checking all materials, equipment and tools before and after use.

4.3.7 The Frequency of Use and the Efficiency of Various Security Measures in Combating Theft on Construction Sites.

From the data description, table 7 reveals contractors' views or opinions on how frequently the various security measures are employed on construction sites and how efficient these security measures are in reducing theft on construction sites. Seven security measures were rated based on their respective means and standard deviations and subsequently ranked.

The employment of watchman was ranked first (1st) as the most frequently employed security measure on construction sites. Use of alarm systems, security cameras, warning signs were ranked seventh (7th), sixth (6th) and fifth (5th) respectively, as the least employed security measures on construction sites in the study area. 
Table 7 The frequency of use and efficiency of current security measures

\begin{tabular}{|l|c|c|c|c|}
\hline A) FREQUENCY OF USE OF CURRENT SECURITY MEASURES ON CONSTRUCTION SITES \\
\hline & $\mathrm{N}$ & Mean & Std. Deviation & Rank \\
\hline Watchman/Security man & 33 & $\mathbf{3 . 7 9 7}$ & $\mathbf{1 . 6 3 0}$ & $1^{\text {st }}$ \\
\hline Security cameras & 33 & 2.727 & 1.126 & $6^{\text {th }}$ \\
\hline Alarm systems & 33 & 2.515 & 0.834 & $7^{\text {th }}$ \\
\hline Fencing and locking gates & 33 & 3.364 & 1.388 & $3^{\text {rd }}$ \\
\hline Lighting the site at night & 33 & $\mathbf{3 . 6 5 8}$ & $\mathbf{1 . 1 1 9}$ & $2^{\text {nd }}$ \\
\hline Use of warning signs & 33 & 2.788 & 1.083 & $5^{\text {th }}$ \\
\hline Marking all plants and equipment & 33 & 3.182 & 1.074 & $4^{\text {th }}$ \\
\hline
\end{tabular}

\begin{tabular}{|l|c|c|c|c|}
\hline \multicolumn{7}{|l|}{ B) EFFICIENCY OF CURRENT SECURITY MEASURES IN REDUCING THEFT ON } \\
CONSTRUCTION SITES \\
\hline \\
\hline Watchman/Security man & N & Mean & Std. Deviation & Rank \\
\hline Security cameras & 33 & $\mathbf{3 . 6 1 5}$ & $\mathbf{1 . 6 6 1}$ & $2^{\text {nd }}$ \\
\hline Alarm systems & 33 & 3.061 & 1.171 & $6^{\text {th }}$ \\
\hline Fencing and locking gates & 33 & 2.758 & 1.091 & $7^{\text {th }}$ \\
\hline Lighting the site at night & 33 & 3.536 & 1.388 & $3^{\text {rd }}$ \\
\hline Use of warning signs & 33 & $\mathbf{3 . 8 7 9}$ & $\mathbf{1 . 3 6 4}$ & $1^{\text {st }}$ \\
\hline Marking all plants and equipment & 33 & 3.152 & 1.004 & $5^{\text {th }}$ \\
\hline
\end{tabular}

How efficient these security measures are in combating theft on construction sites was also calculated and ranked, based on the responses received from the respondents. The employment of lighting the site at night was ranked first (1st) as it had the highest mean mark. Employment of watchman/ security man was also ranked second (2nd), which implies that the two were perceived to be the most efficient security measures in reducing construction site theft and must be provided/employed first before others. Provision of alarm systems is perceived not necessarily effective since it is the only negatively rated security measure (mean below 3.0).

\section{Conclusion}

Though many construction companies can keep costs down with momentary labour staffing, construction site theft can quickly add up to thousands of dollars. Whether it be tools or construction equipment, the cost of replacing parts and equipment — as well as the time spent acquiring new materials — can cause a huge loss of productivity and revenue. For these reasons construction site security and theft prevention are of extreme importance to help you keep costs down and delays to a minimum.

Seven (7) main security measures were subjected to analysis in order to reveal their efficiency in reducing thefts on construction sites in some cases, and their intensity and frequency of use in other cases. These security measures consisted of employing a watchman, use of security cameras, use of alarm system, fencing of site and locking of gates, lighting site at night, use of warning signs and marking plants and equipment. From the analysis of the data obtained from contractors, each of the security measures was ranked according to its mean relative importance in reducing thefts on construction sites that are located in densely populated areas. 'Lighting the site at night' was ranked first (1st) and 'fencing of site and locking of gates' was also ranked second (2nd). 'Security cameras' and 'alarm system' were ranked seventh (7th) and sixth (6th) respectively. The results did not change significantly when the same security measures were tested for their effectiveness in reducing theft when construction sites are located in sparsely populated areas.

Again, the data on the vulnerability of plants, materials and tools to theft was also analyzed.

Contractors rated 'general building materials' as 'very often' stolen from site which was ranked 1st (indicating their frequency of being stolen on sites). Contractors also rated 'small tools and equipment' as 'very often' and none of the contractors rated 'heavy plants and machinery' as 'very often'. The appropriateness and effectiveness of the various security measures in protecting the various plants, materials and tools was also analyzed and from the responses of the contractors, 'Lighting the site at night' was ranked first (1st) as being the most appropriate and effective security measure in protecting both the general building materials and small tools and equipment from being stolen. 'Alarm systems' was ranked seventh ( 7 th) as the least effective and appropriate for protecting both the general building materials and small tools and equipment.

Also, from the analysis, 'Lighting the site at night' 'fencing of site and locking of gates' was rated first (1st) and (2nd) for protecting heavy plants and equipment from being stolen and 'Security cameras' was rated seventh (7th).

Lighting the site at night, fencing of site and locking of gates, and providing of watchman/security man involves less technology and easy to afford in terms of cost whiles use of warning signs, alarm systems and security 
cameras needs higher capital to import expects, technology and materials. These factors might influence the ratings.

\section{Reference}

Ablordeppey, E. E., Dunee, V. A., \& Ahuma-Smith, C (2018). Waste Generation and its Implication to Construction Project Delivery in the Upper West Region of Ghana. International Affairs and Global Strategy - Volume 65

Al-Rifa'y, A.H. (1998). Methods of Scientific Research, Managerial and Economical applications. Dar Wael for Printing and Publishing. Jordan.

Adams, S. (2003). "Securing construction sites”, Site lines. The Official Journal of Local Authority Building Control, Winter ed.

Arata, M. (2006). Construction site security. 1st ed., McGraw Hill book company, New York.

Banks, T. (1990). "Equipment Theft" Constructor, p. $42-43$.

Berg, R. (2003). Jobsite security on commercial construction projects. Master Thesis, Building construction, Graduate school, University of Florida, Florida.

Berg, R. \& Hinze, J. (2005). Theft and vandalism on construction site. Journal of construction engineering and management, 131(7), 826-833.

Boba, R. \& Santos, R. (2006). Burglary at Single-family House Construction Sites, available at: www.cops.usdoj.gov/files/ric/Publications/e08064509.pdf

Bond, J. (2000). Contractors protect tools and equipment from theft, Atlanta Business Chronicle.

Bonesteel, M. (2002). Building Site Crime Prevention Initiatives (BSCP).

Bradley, D. (2005). "Construction-Site Thefts Escalate" The Seattle Times.

Brooks, P. \& Arnold, D. (1989). Reid Report Examiners Manual, Reid Psychological Systems, Chicago, IL.

Carmichael, R., Edwards, D.J. \& Holt, G.D. (2007). "Plant managers' perceptions of plant security systems", Engineering Construction and Architectural Management, Vol. 14, pp. 65-78.

CITS (2011). “Construction Industry Theft Solution Code of Practice." Construction Industry Theft Solution. http://www.cits-uk.org/data/uploads/CITS

Clark, R. \& Goldstein, H. (2003). Reducing theft at construction site: lessons from problem-oriented project. Crime prevention studies, 13, 89-130.

David, J.E. \& Gary D.H. (2008). "Protecting capital investment in plant and equipment: case study observations of post theft recovery", Journal of Financial Management of Property and Construction, Vol. 13 Iss 2 pp. $96-110$.

De Vaus, D. (2002). Surveys in Social Research, $5^{\text {th }}$ ed., Routledge, London.

Donkor, P. (2008). Theft and Vandalism on Industrial and Roofing Construction Projects. available at: http://etd.fcla .edu/UF/UFE00221/donkor_p.pdf

Edwards, D. J., Spittle, P., and Holt, G. (2007). "Plant and equipment theft: a practical guide."http://www.hewden.co.uk/pdf/healthsafety/Plant and Equipment Theft A Practical Guide.pdf

Fadiya, O. O \& Georgakis, P (2012). Perceptions of Building Contractors Concerning Plant Theft' International Journal of Architecture, Engineering and Construction, vol. 1, pp. 47- 54.

Farinloye, O., Mafimidiwo, B., Adewunmi, Y. \& Ajayi O. (2009). Prevalence of theft and vandalism on building site. Proceeding of the RICS COBRA Conference University of Cape Town, South Africa, 150-164.

Felson, M. (1998). Crime and Everyday Life (2nd ed.). Thousand Oaks,CA: Pine Forge Press.

Green, G.S. (1997). Occupational Crime, 2nd ed., Nelson-Hall, Chicago, IL.

Gregory, J. (2007). "Security guidance document for agricultural and construction plant." Report no., Publication Number 64/01, Police Scientific Development Brach, Home Office Policing and Crime Reduction Group.

Harris, F. (1994). Modern Construction and Ground Engineering Equipment and Methods, 2nd ed., Longman, Harlow.

Jeffrey, M. (2001). An analysis of the extent and nature of theft of equipment within the construction industry, August 2001. Report no. 1, MEL ref (2001-002). Prepared for Civil Contractors Federation - NDW OAMPS Insurance Brokers Ltd Hire and Rental Industry Association.

Jennings, P. \& Holt, G.D. (1998). "Prequalification and multi-criteria selection: a measure of contractor's opinions", Construction Management and Economics, Vol. 16, pp. 651-660.

Kamp, J. \& Brooks, P. (1991). "Perceived organizational climate and employee counter productivity", Journal of Business and Psychology, Vol.10 No. 4, pp. 447-58.

Patrick S. (2011). "We stop plant theft and unauthorised use." KOSRAN Electro-Mechanical Immobilisation \& Plant Asset Management. http:// www.harperplant.co.uk/pdf/kosran.pdf (accessed 2011/07/05).

Lang, R. (2008). Health and safety on construction site - construction international. Available at: http://www.tag-guard.com.

Lee, K. (2002). Building site crime prevention initiative: final report (August 2001 - June 2002). Melbourne: Crime Prevention Victoria 
LoJack Corporation. (2006).“Construction Equipment Theft Study” http://www.lojack.com/pdf/constructiontheft-study.pdf (Nov. 25, 2007).

Mawby, R. (2001). Burglary, Devon, Willan

Naoum, S.G. (1998). Dissertation Research and Writing for Construction Students. Reed Educational and Professional Publishing Ltd. Butterworth Heinemann.

Newman, O. (1973). Architectural Design for Crime Prevention. U.S. Government Printing Office: Washington, DC.

O’Malley, S. (2005). "Homeland Security: Thieves Steal 4 billion a year from American Jobsites. Here Are 10 Steps to Help Protect Yours."

http://findarticles.com/p/articles/mi_m0JVJ/is_3_16/ai_nl3809125 (Dec. 13, 2007).

Odeyinka, H. A. (2000). "An evaluation of the use of insurance in managing construction risks", Construction Management and Economics, Vol. 18 No. 5, pp. 519-24.

Polit, D. F., \& Hunglar, B. P. (1999). Nursing Research Principles and Methods. 6th edition. Lippincott Williams \& Wilkins. Philadelphia.

Premo, M. (n.d.). Construction site security white paper, US operations, EMZA visual sense.

Purbrick, T. (2003). "Demolition gang” Police review, 12 September.

Raiden, A.B., Dainty, A.R.J., \& Neale, R.H. (2003). "A strategic employee resourcing framework (SERF) for construction', in Greenwood, D.J. (Ed.), Proceedings of the 19th Annual ARCOM Conference, University of Brighton, 3-5 September, Vol. 1, The Association of Researchers in Construction Management, Sheffield, pp. 223-32.

Smith, A., Walmsley, R. (1999). The nature and extent of construction plant theft. Police research series no. 117. London: Home Office Survey System, (2004). Survey System's Tutorial, Revised 3/5/2004. Creative Research System. http://www.surveysystem.com/ssformu.htm.

Taylor, R. R., \& Prien, K. O. (1986). Preventing employee theft: A behavioral approach. Busines Perspectives, 10(4). (Retrieved August 12, 2009). from ABI/INFORM Global. (Document ID:34025418).

Walker, A. (2002). Project Management in Construction, Blackwell Publishing, Oxford.

Yulia, S,. (2008). "Construction site security management and control”, Master of Science Thesis, Faculty of civil engineering, University Teknologi, Malaysia.

Zemke, R. (1986). "Employee theft: how to cut your losses", Training, May, pp. 74-8.

Ayyub, B.M., Mccuen, R.H. (2003). Probability Statistics and Reliability for Engineers and Scientists. $2^{\text {nd }}$ edition. Chapman and Hall/CRC Press Company. Boca Raton. USA 